\title{
A Contemporary Commemoration of the Dead: Yyr-pyd s'oton in Southern Udmurtia
}

\section{Denis Kornilov}

e-mail: denkornilove@gmail.com

\begin{abstract}
The subject of the article is a description of one of the major commemorative rituals of the Udmurt, the yyr-pyd s'oton, 'giving away of the head and legs (of an animal)' supplemented by pictures. This particular traditional commemoration with innovative elements was conducted in the village of Bagrash-Bigra in Malaya Purga district, Udmurt Republic in September, 2021 in honour of those who died during the Great Patriotic War ${ }^{1}$.
\end{abstract}

Keywords: ancestor commemoration, photographic evidence, tradition and innovation, Udmurt, yyr-pyd s'oton ritual

The yyr-pyd s'oton 'giving away of the head and legs (of an animal)' ritual is one of the major rituals in the system of the ancestor cult that regulates - according to belief - relationships with dead ancestors in time and space. It is also known in various local traditions by other names: val s'uan 'the steed's wedding', myddorin / ber s'uan 'the wedding inside out / the last wedding', ly potton 
'taking out / bringing out of the bones (of the sacrificial animal)' (Atamanov, Vladykin 1985; Vladykin, Churakova 1986; Vladykin 1994: 169-179; Minniyakhmetova 2000: 57-59; Shutova 2001; Vladykina 2004; Sadikov 2004: 123; Anisimov 2017: 168-271; Vladykina et al. 2021; and Anisimov 2021 in this issue).

Unlike other annual calendar-connected memorials such as kis'ton 'libation', the ritual is aimed at a one-time commemoration of dead parents:

...everyone in their life was obliged to go through this rite at least once. A cow was sacrificed for the mother, a horse for the father. It was believed that with the parents' commemoration (three, five, seven years after the death and later, but not earlier than a year after the funeral) 77 generations were being commemorated (77 vyzhy kulem"yos). These ancestors might be supportive towards the living if they are commemorated, or, on the other hand, could cause damage and do harm if disrespected. The time of the ritual was supposed to correspond strictly with the calendar. Usually it was held in deep autumn, at the time of butchering; according to an unspoken instruction the date was supposed to be before the winter solstice, i.e. before December $25^{\text {th }}$. We find local reminders of this rite in the form of cooking ritual dishes from the head and legs of the butchered animal during winter holidays not later than Maslenitsa (Vladykina, Glukhova 2011: 74).

The commemoration was included in a number of family rituals when a particular family organised a sacrifice and invited their patrilineal relatives, the böl'ak. It was thought that the late parents protected the livestock making the sacrifice of a large animal obligatory. The basic stages of the ritual were the butchering of the animal and the cooking of sacrificial body parts, i.e. the head and the legs which, it was believed, were the 'skeleton' of the animal 
and were endued with the ability to transfer its soul so that it could set off and pass from this world to the other. All the family, as well as the invited kin, took part in the banquet. After being separated from the flesh the large bones and skull were collected in a basket and the family put them together with kumyshka (moonshine), bits of ritual dishes, coins, basma sep (fabric shreds) cut by scissors but not woven together, tiny dresses and a shirt. The feast was accompanied by a special song that addressed the dead to receive the sacrifice, with the sacrifice characterised as "fast running", "gold/ silver hooved", as having "golden horns" or "an udder with six nipples" (Vladykin, Churakova 1986: 129-133). The basket was taken out of the yard on a sledge by a 'married couple', a pantomime of a male-female duo. The procession consisted of a few people basically of old age and children going to a special place marked by a tree, most frequently a fir tree. The large bones and the skull were hung on branches, small bones and the content of the basket was piled up at the roots. On returning to the village, the procession says of those who were commemorated: auntie (name) or uncle (name) said that they lived well and wished to everybody health, wealth and happiness.

Time induces changes in the practice of rituals. Tradition doesn't necessarily become dogma, it can change depending on life conditions. We had the opportunity to confirm this using the example of the yyr-pyd s'oton commemorative ritual in Bagrash-Bigra village in the Udmurt Republic ${ }^{2}$.

Malaya Purga district is one of the southern districts of Udmurtia. Here some traditions are still alive or are being revitalised. Specifically in this village the position of elder of the clans and of the elected elder of the village has been re-established, a position currently held by former history teacher Anatoliy Yakovlevich Matveev. A unique building was built by the citizens, according to the veme custom, to become the village museum, the Daur shykys culture centre (Photo 24). Many members of the village community can speak about the history of the village through the history of 
their families. Thus, Vladimir Fedoseevich Botnikov, former engineer, remembers that his clan includes almost 200 people. He was able to remember the details of many family calendar rituals, organize them and tell young people about them (Photo 20).

According to Vladimir Matveev the idea of holding a commemorative ritual in honour of the Great Patriotic War ${ }^{3}$ dead was raised a long time ago: "Many of them even didn't have time to form families. Who could remember them but us? It's our duty. Some of them have families: wives and children. But many of them are not alive anymore". This idea was never more suitable than at the $75^{\text {th }}$ anniversary of victory: "An odd number of years should pass for a yyr-pyd s'oton ritual, both seven and five are the numbers that fit. So we decided this year to commemorate all our dead". They visited all families whose relatives went to the Army and didn't return, announcing a gathering of donations and putting out a special box at the village shop (Photo 3). The wish to perform this ritual in spring coincided with coronavirus prohibitions. But the promise was made and it made many citizens of the village restless. Failure to keep this promise, according to the tradition, caused undesirable consequences such as illness, livestock deaths and misfortune in many undertakings. This is why in more or less favourable circumstances the decision was made to conduct the ritual together with the spring-summer vös' ritual in honour of the end of sowing and to promote a good harvest (which was also not held because of quarantine measures). The combining if the rituals doesn't seem to fit the framework of tradition, but what was thought and said had to be fulfilled. A date and place were agreed: September $12^{\text {th }}$ in the gully called Bign'uk, where formerly rituals were performed (Photo 1). The organisers tried to take into account the distance from the villages of Bagrash-Bigra and Orlovo (Udm. Orloy) so that elder people would be able to attend the ceremony. Although the day chosen was at the weekend, there were fewer participants than expected, which can be explained as being the result of the general quarantine situation. 
The location used to host the cheka vös' commemorative ritual, in which all ancestors were commemorated. Everyone from the village attended this ritual. But yyr-pyd s'oton is a commemoration of a particular family, commemorating the parents, the father or the mother, the husband or the wife. One day before the ritual, the heads of the kin groups, böl'ak kuz'oos, chose a sacrificial priest, called the kuris' (literally the one who begs/prays). Two assistants were appointed from the family of Bagrash and Akan to kill the sacrificial animal, the sugymlyk vandis' (literally stabbing a sacrifice - sugymlyk (Tat.) is a sacred animal fed for butchering, Tarakanov 1993: 114), because, according to the tradition, the sacrificial priest could not participate in this process. Cooks were also appointed.

With the donations from the population, both a ram (for the vös'ceremony) and a young bull (for the yyr-pyd s'oton ritual) were bought from the villagers. The ram was slaughtered at the ritual place, the bull in the village. Meat from the ram and the head of the calf were cooked in separate cauldrons (Photos 2,4). The sacrificial food for the vös'ceremony was sanctified separately (Photos 15-17).

An interesting detail about the surroundings of the ceremonies was the 'table' and the specially painted huge cable adapted for this ritual. It was brought to the location on a cart drawn by a tractor, as with the rest of the paraphernalia. The table was covered with an old white sheet, which was used at home only in sacred situations (Photo 5). The participants of the ritual put on the table the food offered as a donation (Photos 6, 7). Earlier, during the vös' ceremonies, there were no tables. Dishes with sacrificial food were placed at a specially prepared location under a tree.

It is no less important to pay attention to the garment of sacrificial priest Vladimir Botnikov. To sanctify the dishes and perform the ritual he put on a special frock (Udm. dukes) and headgear, and girt himself with a ritual waist belt (Udm. kuskertton / puto), while special rules had to be taken into account to place the ends of the 


\section{Denis Kornilov}

belt on the side (Photos 8-10). It's noticeable that all ritual clothes are new, and the fabric of the frock has not been bought but woven.

The scenario of the ritual included particular mise-en scènes which were important for this particular situation. After a preliminary sanctifying of the ritual food, representatives of the local authorities took the floor. A. Matveev spoke about the figures of those who went to the War and those who fell, about the hard labour of those on the home front (Photo 12). Alongside chuk in the form of ordinary rags and strips, old women fastened brown and black St George's ribbons to the tree. To make it easier to tie chuk to the tree screws were placed in the trunk (Photos 13, 14).

The ritual was completed by traditional eating and drinking (Photos 22, 23). The promise was kept. This ceremony was embedded in the participants' memory not as an ordinary event, but as a duty fulfilled, an offering for the souls of fallen fellow-villagers. According to Vladimir Botnikov, "this prayer could happen only once".

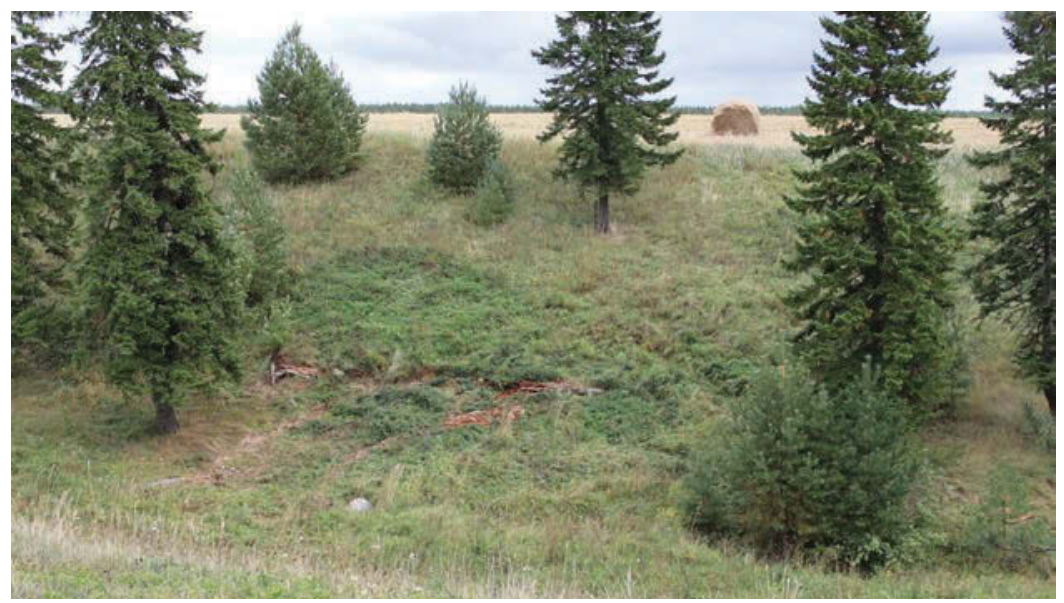

Photo 1. Bign'uk gully, the former ritual location. 


\section{A Contemporary Commemoration of the Dead}

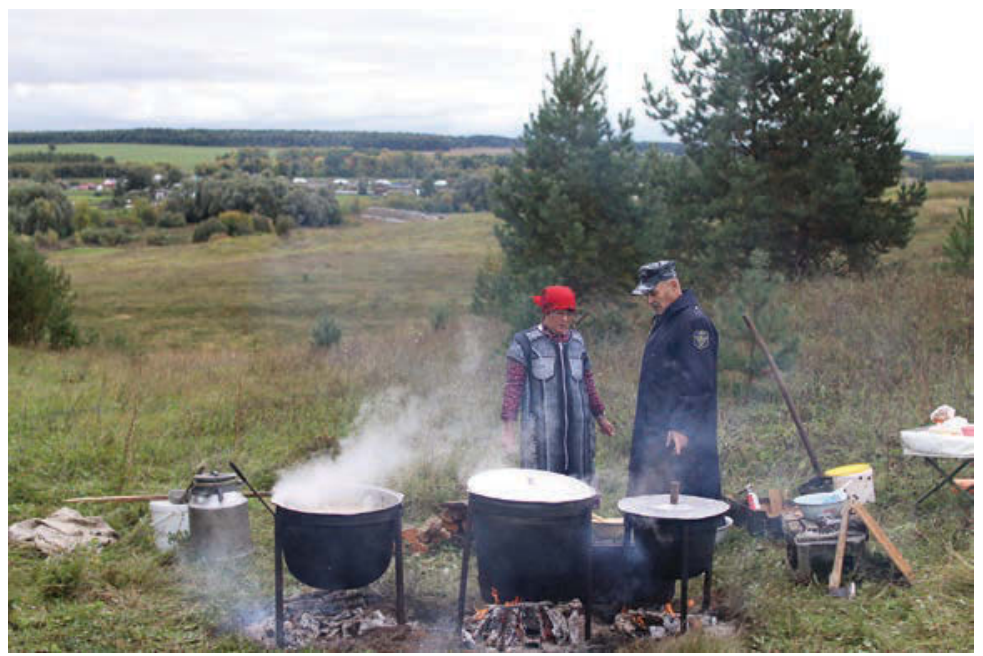

Photo 2. Preparation of the sacrificial food: porridge, and meat from the sacrificial animal's head.

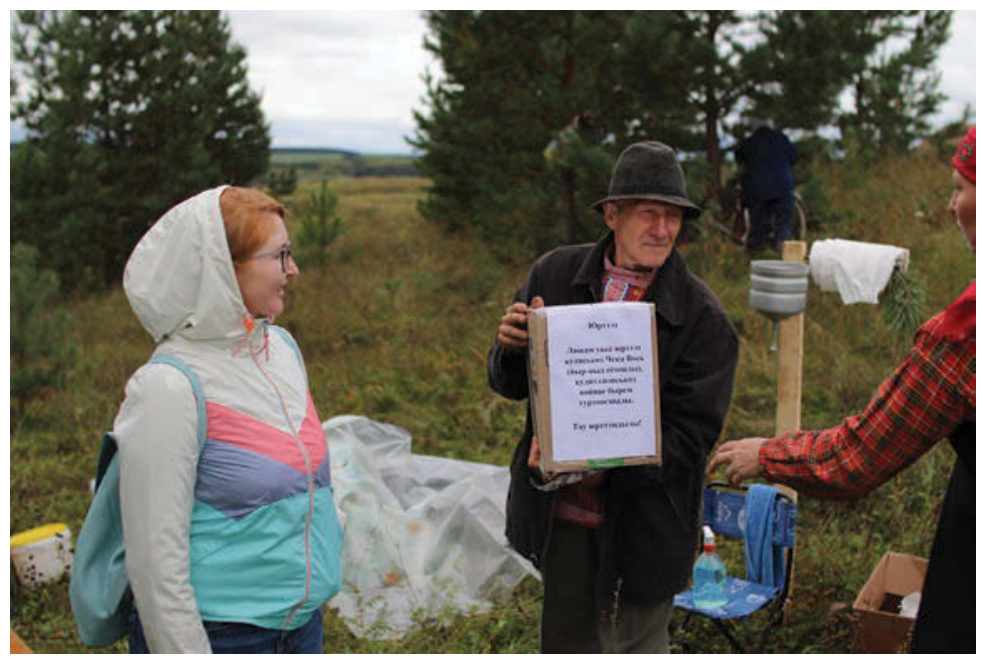

Photo 3. The donation box with a message reading: "Help. The collected funds will be used for the Cheka vös' ritual, which will be devoted to those who didn't return from the War. Thanks for your help!" 


\section{Denis Kornilov}

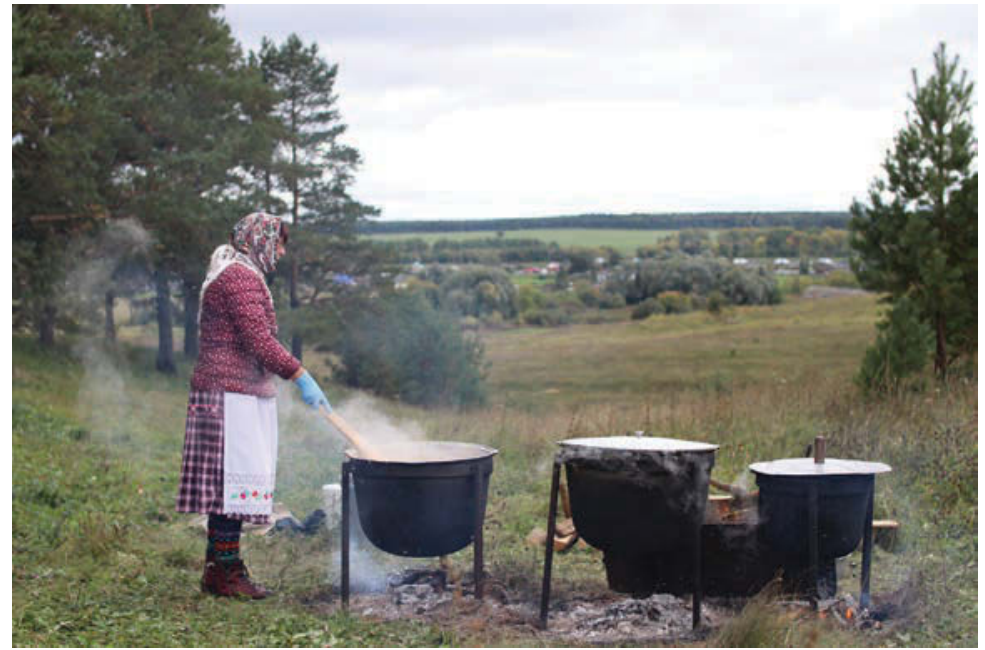

Photo 4. Preparation of the sacrificial food for the vös' and yyr-pyd s'oton ceremonies in separate cauldrons.

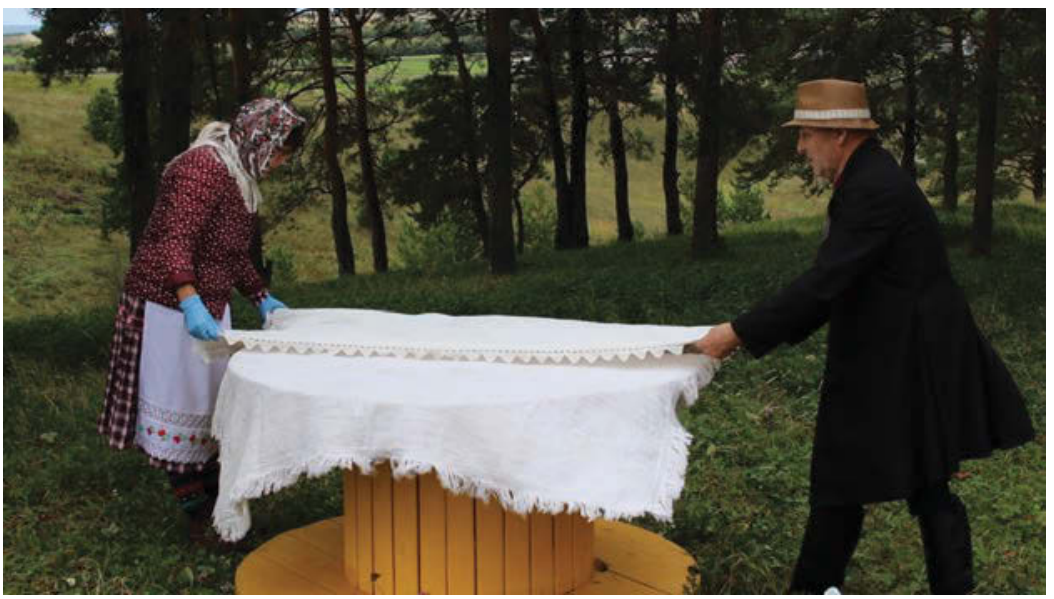

Photo 5. The table for offerings from participants in the ritual. 


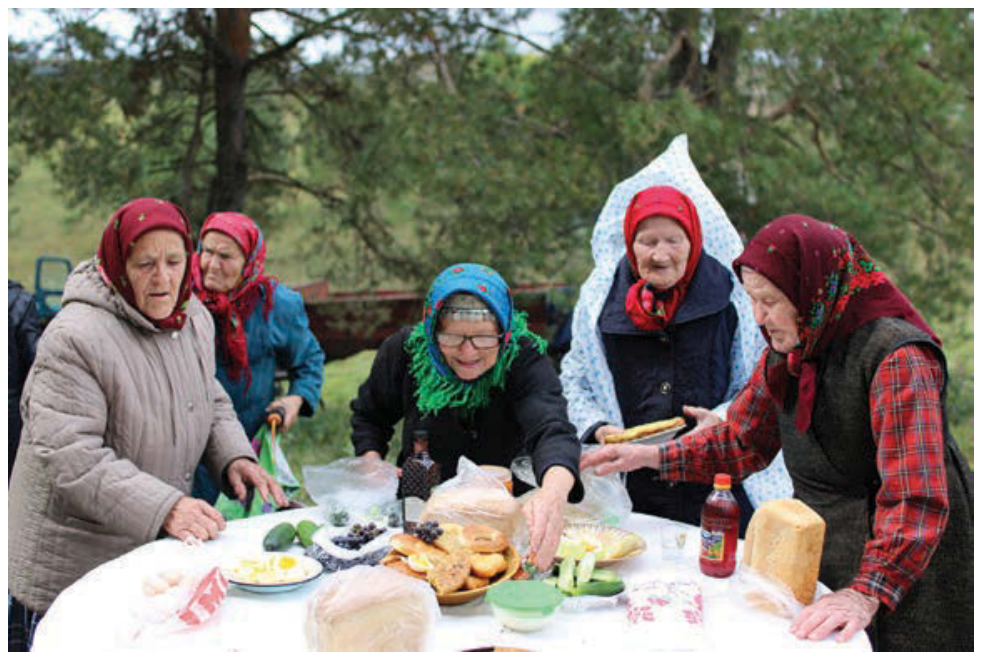

Photo 6. Offerings from the villagers of Bagrash-Bigra and Orlovo.

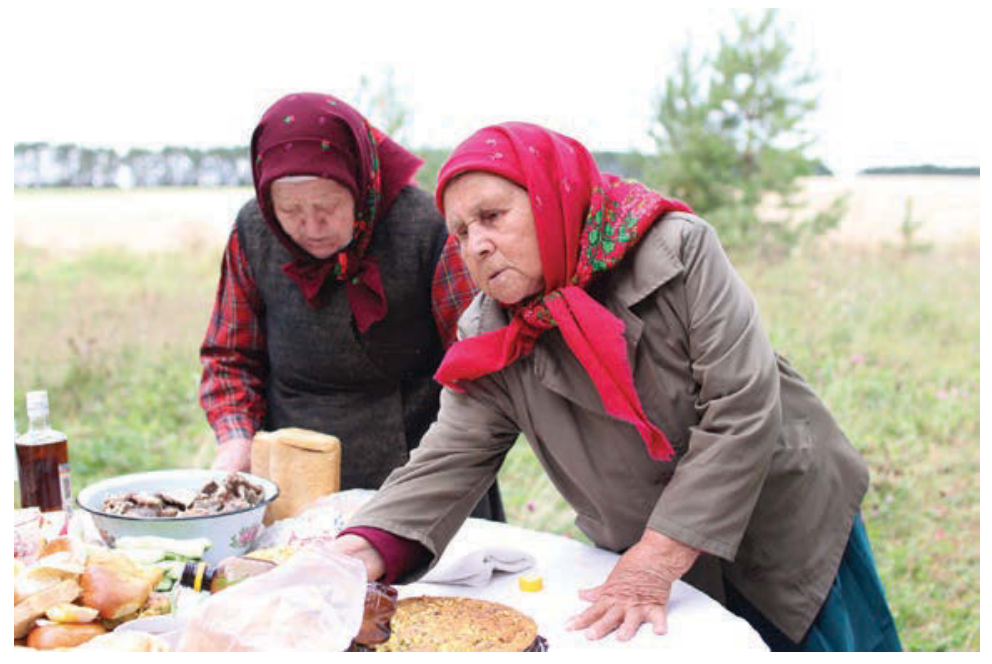

Photo 7. A participant in the ritual pours her moonshine (kumyshka) into the common vessel. 


\section{Denis Kornilov}

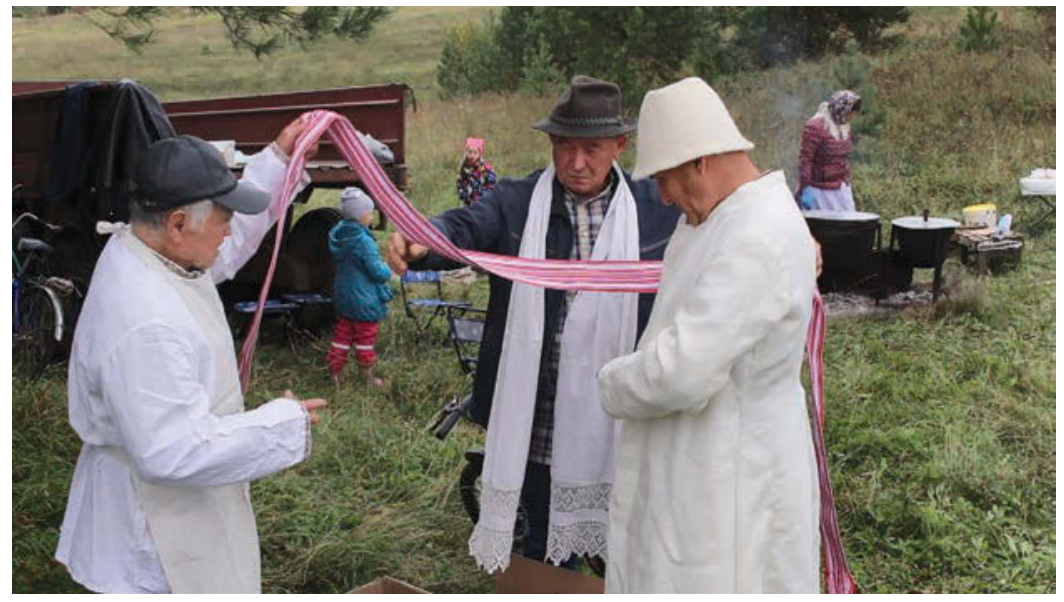

Photo 8. The assistants help the sacrificial priest put on ritual clothes.

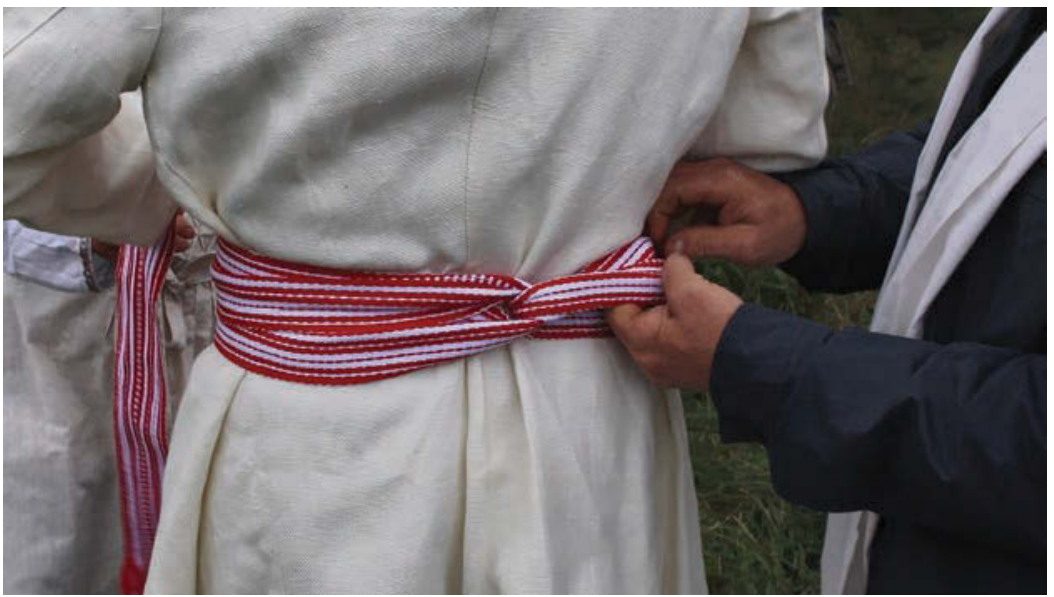

Photo 9. Prayer belt (rear view). 
A Contemporary Commemoration of the Dead

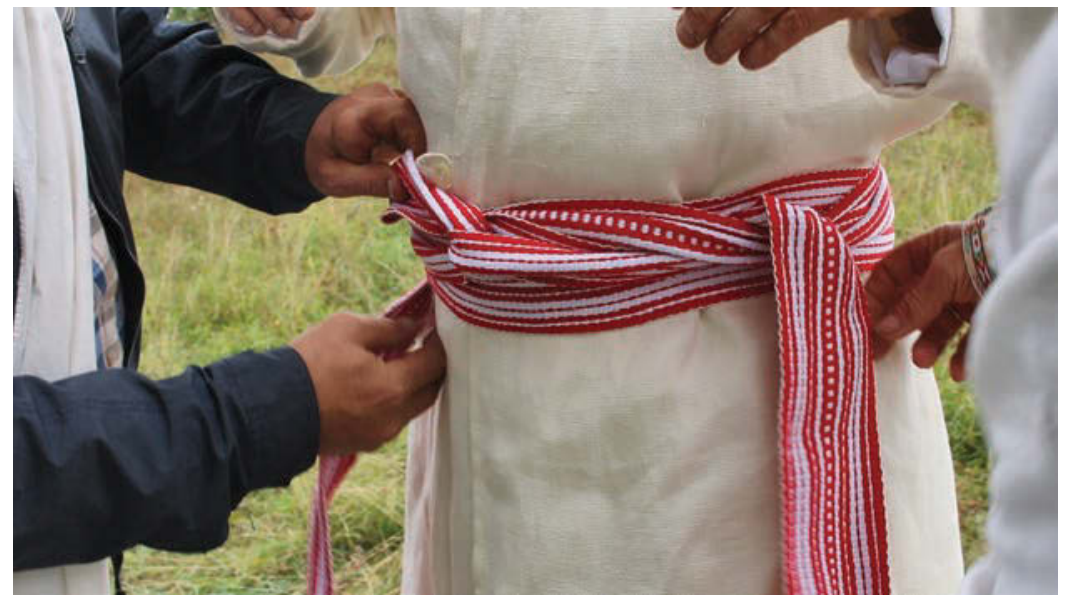

Photo 10. Prayer belt (front view).

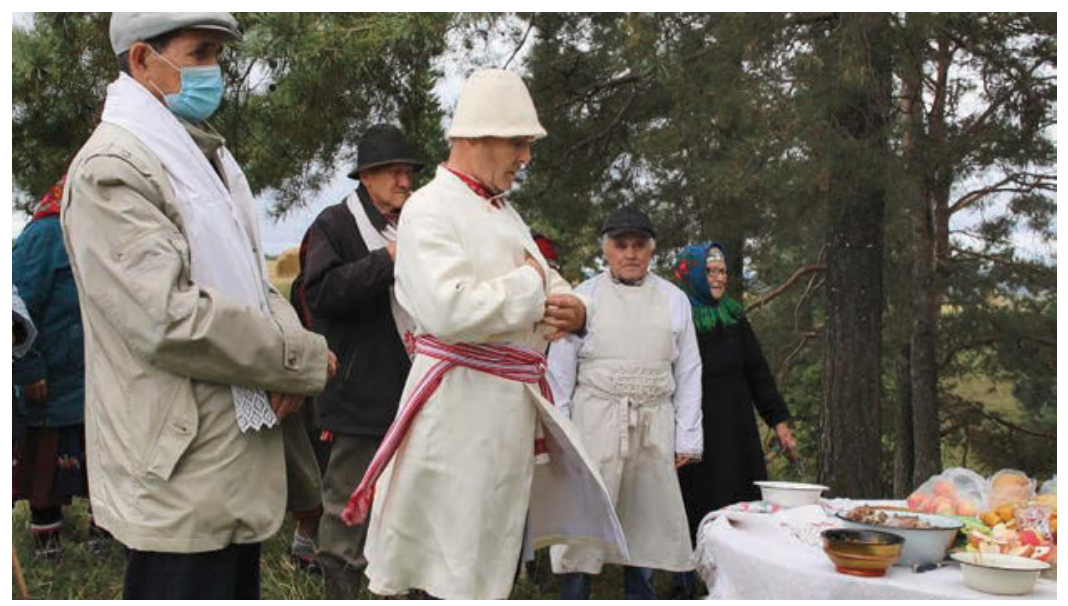

Photo 11. The first stage of the prayer (kuris'kon). 


\section{Denis Kornilov}

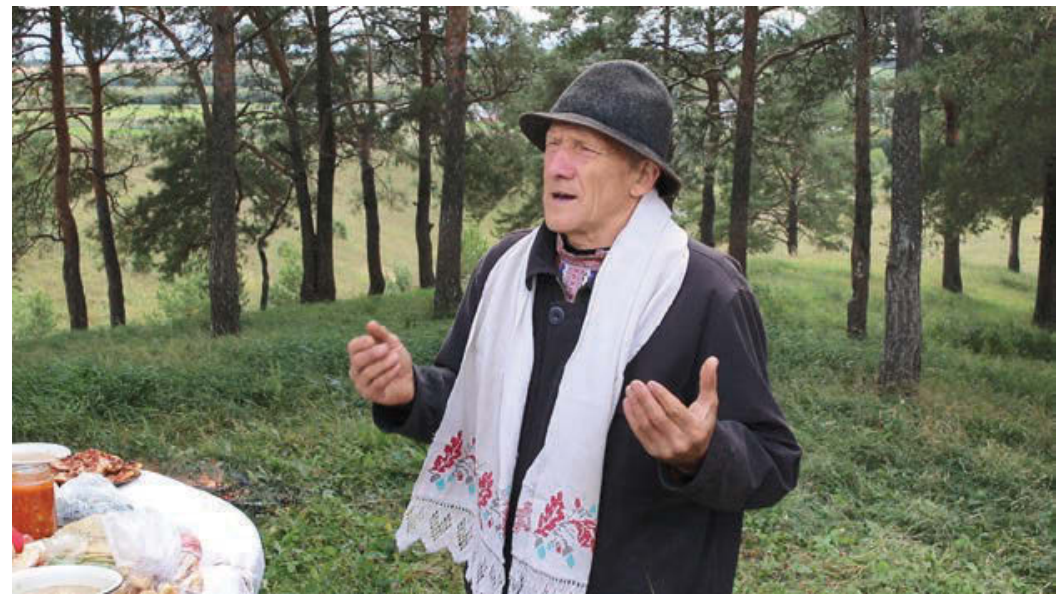

Photo 12. Village elder Anatoliy Yakovlevich Matveev speaks about the War.

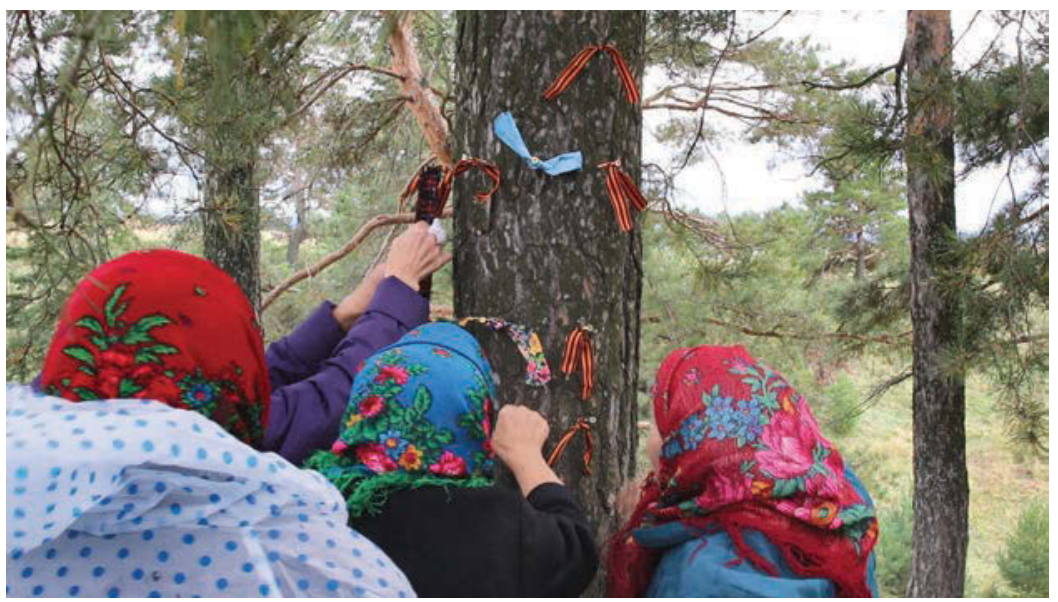

Photo 13. Offerings in the form of chuk strips. 
A Contemporary Commemoration of the Dead

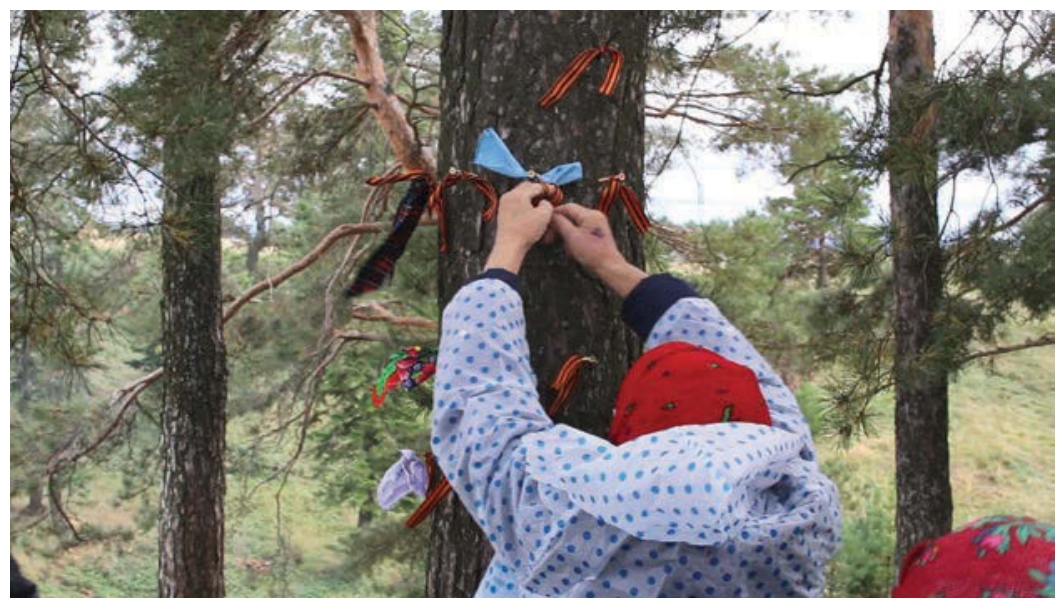

Photo 14. Sacrifice/gift chuk strips.

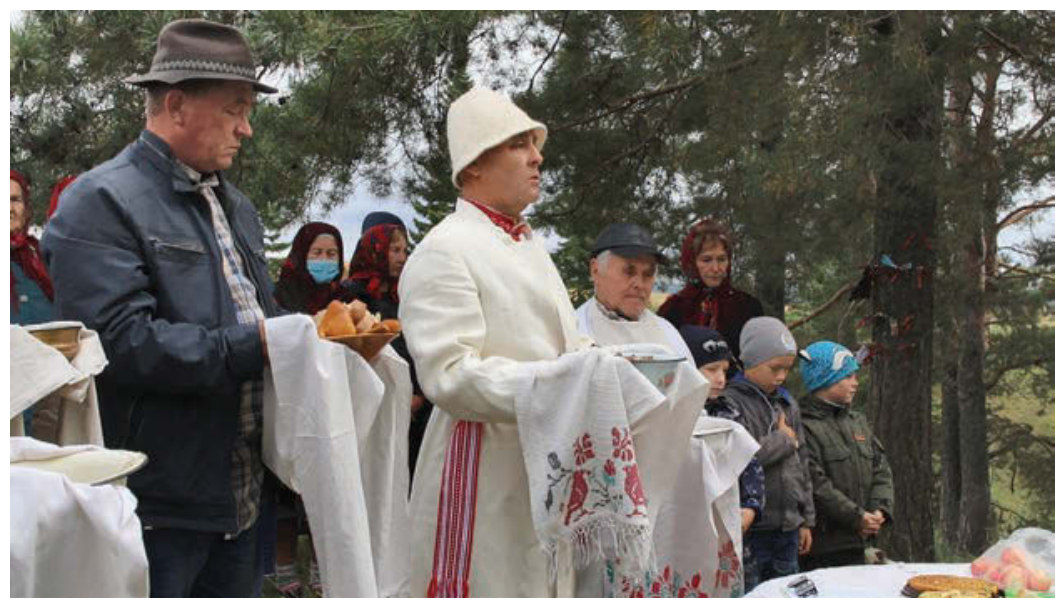

Photo 15. Sanctifying the food for the vös'ceremony. 


\section{Denis Kornilov}

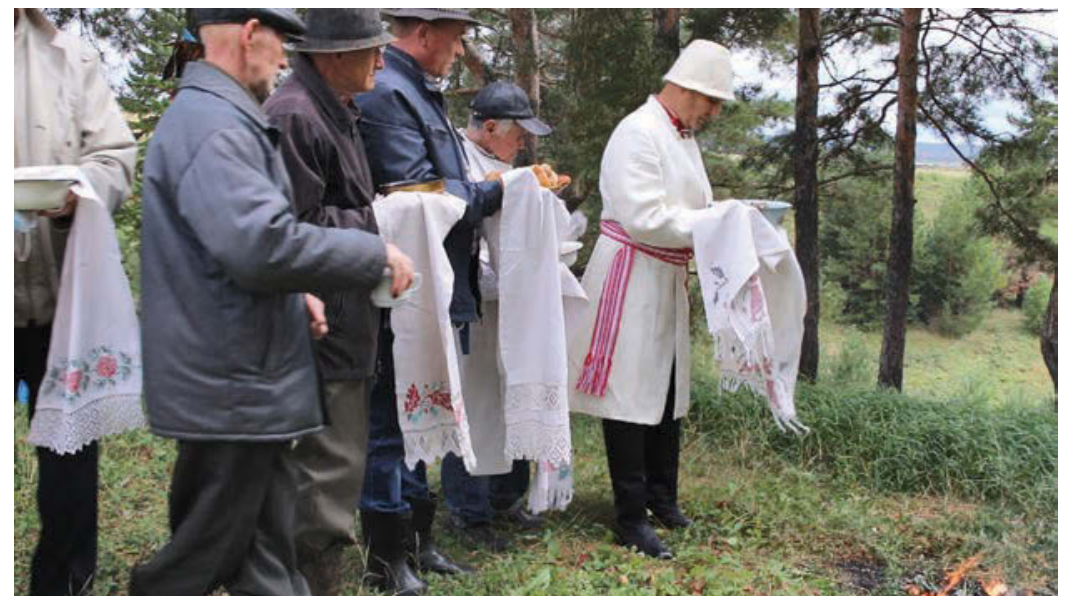

Photo 16. Sanctifying the food for the vös' ceremony.

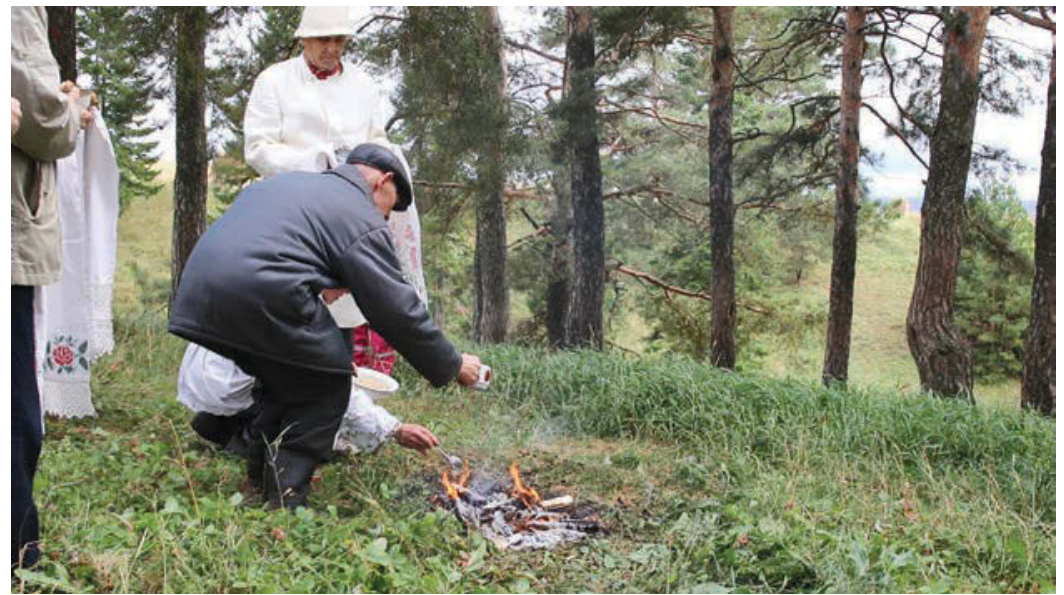

Photo 17. Sacrificing the ritual food and drink for the vös'ceremony. 
A Contemporary Commemoration of the Dead

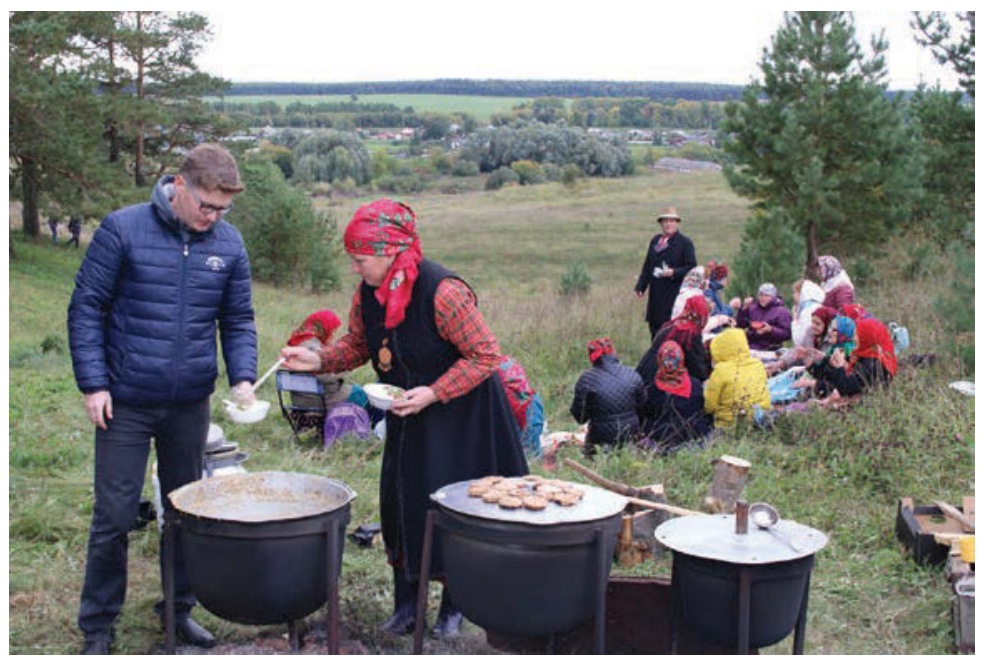

Photo 18. Ritual banquet.

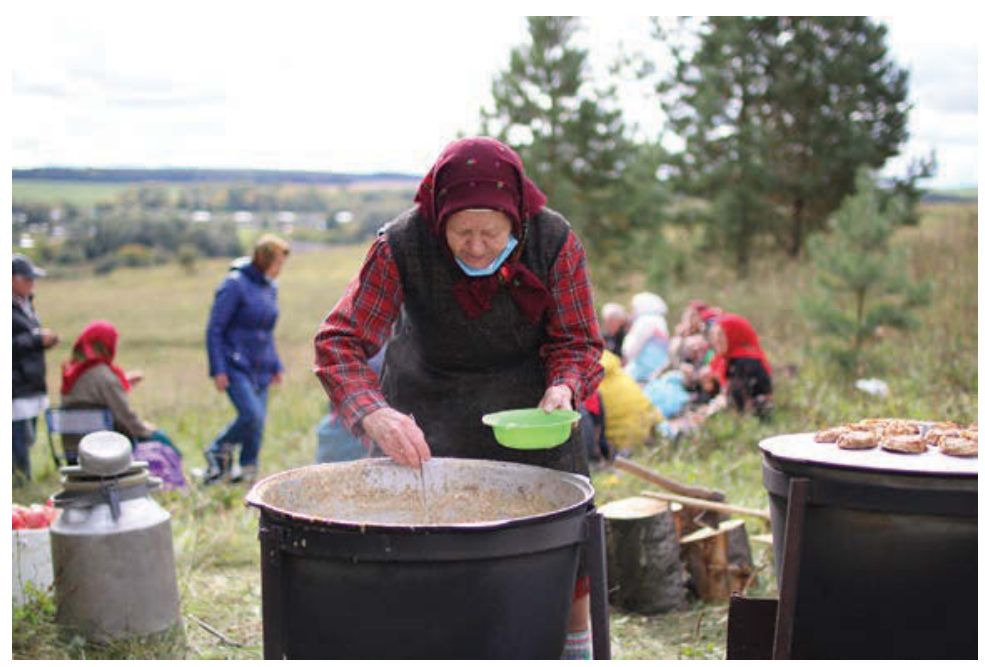

Photo 19. Ritual banquet. 


\section{Denis Kornilov}

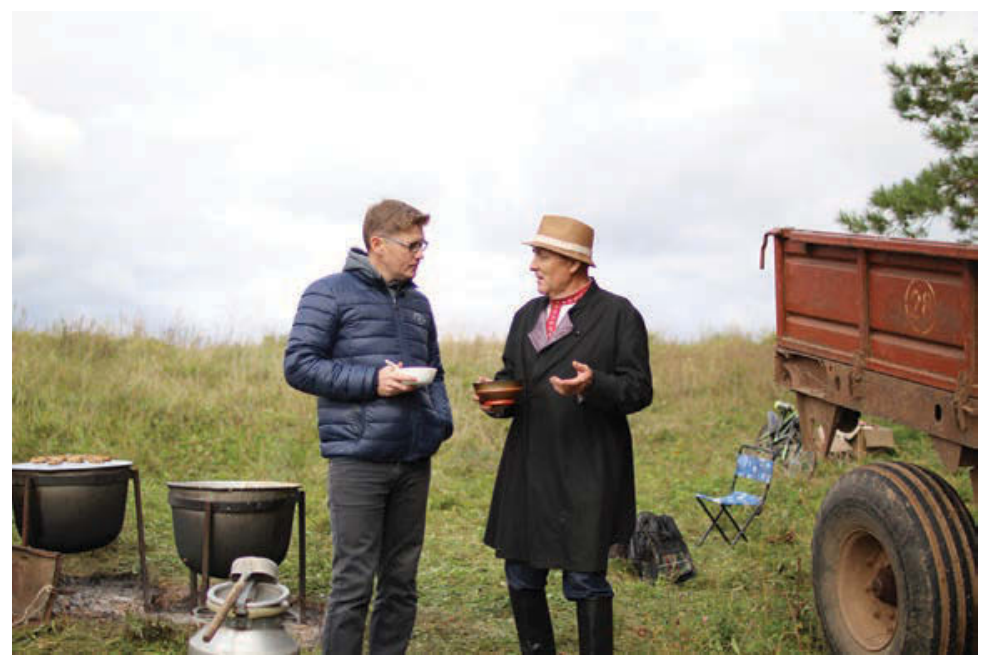

Photo 20. Vladimir Fedoseevich Botnikov speaks about the peculiarities of the ritual.

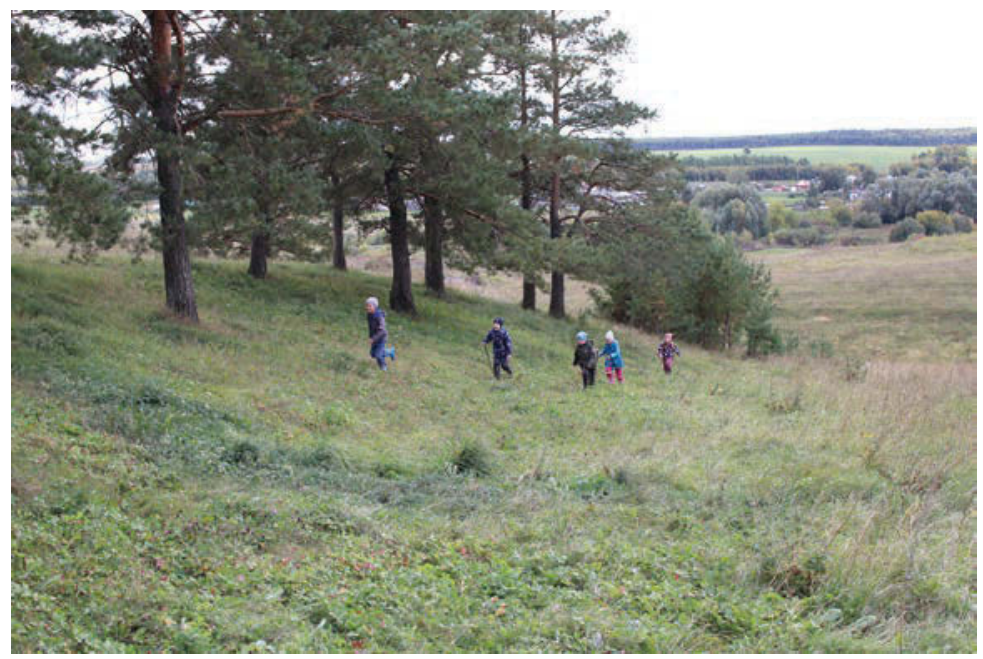

Photo 21. Children running to the ritual location. 


\section{A Contemporary Commemoration of the Dead}

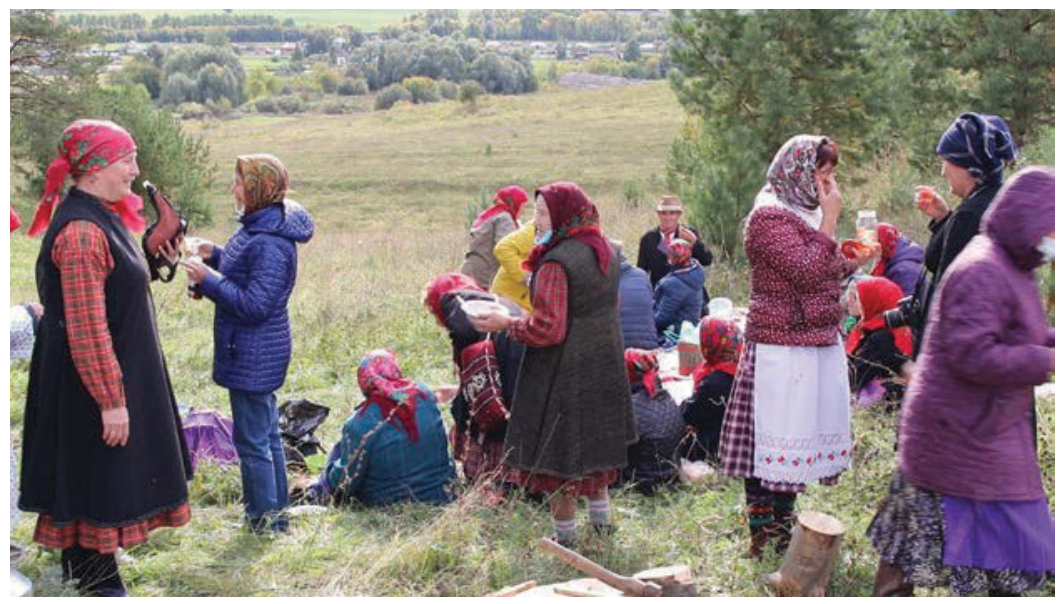

Photo 22. Common eating-and-drinking of the ritual participants.

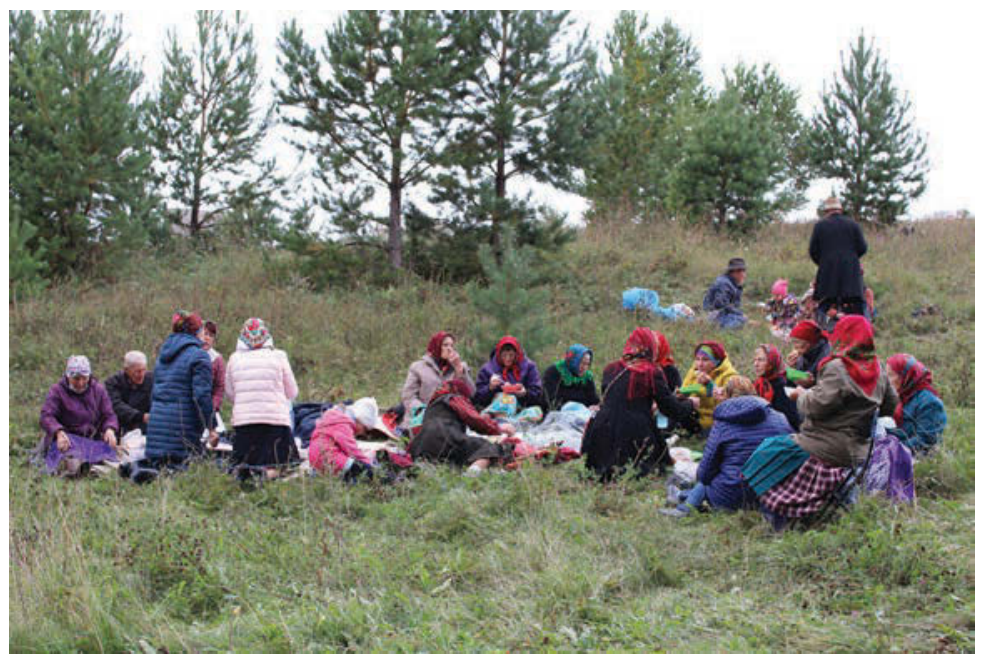

Photo 23. Common eating and drinking of the ritual participants. 


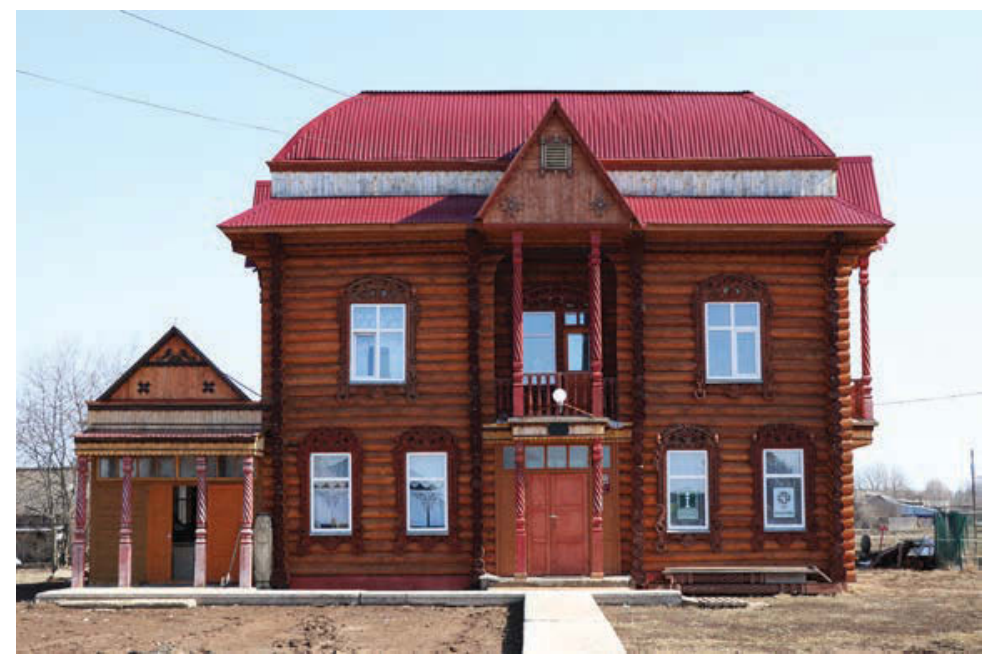

Photo 24. Daur shykys cultural centre in Bagrash-Bigra.

\section{Notes}

1 The Russian name for the Second World War.

2 Videos of the ritual and testimonies of its participants were recorded on September $12^{\text {th }}, 2020$ during a combined UIIYaL FITs UrO RAN (Denis Kornilov) and Republic House of Folk Arts (Veronika Fedorova) expedition.

3 This is the name used in Russia for World War II whose dates are not the same than for the West, for Russia it is encompassed between 1941 and 1945. 


\section{References}

Anisimov, N. 2017. "Dialog mirov" v matritse kommunikativnogo povedeniya udmurtov: dis. ... doktora filosof. po fol'kloristike ["Dialog of the Worlds" in the Matrix of the Communicative Behaviour of the Udmurts: Dis. ... Doctor of Philosophy in Folkloristics]. Tartu: University of Tartu Press.

Anisimov, N. 2021. Simvolika odezhdy umershego v traditsionnoy kul'ture udmurtov [Symbolics of the Clothes of the Dead in the Traditional Culture of the Udmurts]. Predmetnyye realii udmurtskoy etnokul'tury: Kollektivnaya monografiya [Objects as Elements of the Udmurt Ethnic Culture: Collective Monography]. Pod obshch. red. Vladykinoy T. G. [Ed. T. G. Vladykina]. Izhevsk: UdmFITs UrO RAN, pp. 58-69.

Atamanov, M., Vladykin, V. 1985. Pogrebal'nyy ritual yuzhnykh udmurtov (kon. XIX - nach. XX vv.) [Funeral Ritual of the Southern Udmurts (End of XIX Century - Beginning of XX Century)]. Materialy srednevekovykh pamyatnikov Udmurtii [Materials of the Middle Age Monuments of Udmurtia]. Ustinov: SRI, pp. 131-183.

Minniyakhmetova, T. 2000. Kalendarnyye obryady zakamskikh udmurtov: Monografiya [Calendar Rituals of the Udmurts beyond the Kama River: Monograph]. Izhevsk: Udmurtskiy institut istorii, yazyka i literatury Uralskogo otdeleniya Rossiyskoy akademii nauk.

Sadikov, R. 2004. Svyatilishcha zakamskikh udmurtov: Obshchaya kharakteristika i tipologiya [Sanctuaries of the Udmurts from beyond the Kama River: General Characteristics and Typology]. Kul'tovyye pamyatniki Kamsko-Vyatskogo regiona: Materialy i issledovaniya: Sb. st. [Cult Monuments of the Kama-Vyatka Region: Materials and Researches: Coll. of Articles]. Otv. red., avt. predisl. N. I. Shutova. [Ed. and the Preface's Author N. I. Shutova]. Izhevsk: Udmurtskiy institut istorii, yazyka i literatury Uralskogo otdeleniya Rossiyskoy akademii nauk, pp. 119-124.

Shutova, N. 2001. Dokhristianskiye kul'tovyye pamyatniki v udmurtskoy religioznoy traditsii: Opyt kompleksnogo issledovaniya [Pre-Christian Cult Monuments in the Udmurt Religious Tradition: Experience of the Integrated Study]. Izhevsk: Udmurtskiy institut istorii, yazyka i literatury Uralskogo otdeleniya Rossiyskoy akademii nauk.

Tarakanov, I. 1993. Udmurtsko-tyurkskiye yazykovyye vzaimosvyazi (Teoriya i slovar'). [Udmurt-Turkic Language Interactions (Theory and Dictionary)]. Izhevsk: Publishing house of the UdGU. 
Vladykin, V. 1994. Religiozno-mifologicheskaya kartina mira udmurtov. [The Udmurts' Religious-Mythological Worldview]. Izhevsk: Udmurtia.

Vladykin, V., Churakova, R. 1986. Obryad "yyr-pyd s'oton” v pominal'nom rituale udmurtov [The Ritual "yyr-pyd s'oton" in the Commemorative Ritual of the Udmurts]. Muzyka v svadebnom obryade finno-ugrov $i$ sosednikh narodov [Music in the Wedding Ritual of Finno-Ugrians and Neighbouring Peoples]. Tallinn: Eesti Raamat, pp. 108-133.

Vladykina, T. 2004. Znayushchiy (tuno) v udmurtskoy traditsionnoy kul'ture [The One Who Knows (Tuno) in the Udmurt Traditional Culture]. Udmurtskaya mifologiya [Udmurt Mythology]. Izhevsk: Udmurtskiy institut istorii, yazyka i literatury Uralskogo otdeleniya Rossiyskoy akademii nauk, pp. 97-102.

Vladykina, T., Glukhova, G. 2011. Ar-god-bergan: Obryady i prazdniki udmurtskogo kalendar'ya [Year-Circle: Rituals and Celebrations of the Udmurt Calendar]. Izhevsk: Udmurtskiy universitet.

Vladykina et al. 2021 = Vladykina, T., Glukhova, G., Panina, T. 2021. Chuk v traditsionnoy kul'ture udmurtov [Chuk in the Traditional Culture of the Udmurt]. Predmetnyye realii udmurtskoy etnokul'tury: Kollektivnaya monografiya [Objects as Elements of the Udmurt Ethnic Culture: Collective Monography]. Pod obshch. red. Vladykinoy T. G. [General ed. T. G. Vladykina]. Izhevsk: UIIYaL UrO RAN, pp. 36-49.

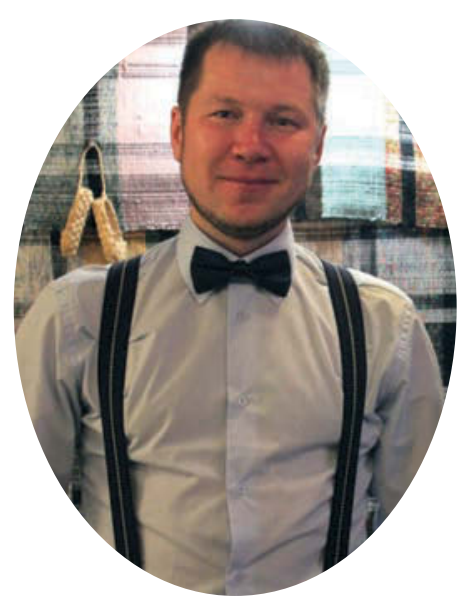

Denis Kornilov is a junior researcher at the Department of Philological Studies at the Udmurt Institute for Research in History, Language and Literature (Udmurt Federal Research Centre of the Ural Branch of the Russian Academy of Sciences). He is the author of anthropological films and investigates possible ways of using high-tech in studying the traditional culture of the Udmurt. e-mail: denkornilove@gmail.com 